\title{
Circulating levels of vitamin D, vitamin D receptor polymorphisms, and colorectal adenoma: a meta-analysis
}

\author{
Jung Eun Lee ${ }^{\S}$ \\ Department of Food and Nutrition, Sookmyung Women's University, 52 Hyochangwon gil, Yongsan-gu, Seoul 140-742, Korea
}

\begin{abstract}
Growing evidence suggests an elevated risk for colorectal neoplasia among individuals with low levels of vitamin D, the biological actions of which are mediated by the vitamin D receptor (VDR). To investigate the association among vitamin D status, VDR polymorphisms (FokI, and BsmI), and colorectal adenoma, we conducted a meta-analysis of nine studies of circulating levels of 25-hydroxyvitamin D (25(OH)D) and five studies of FokI or BsmI polymorphisms in relation to colorectal adenomas. Study-specific relative risks (RRs) and 95\% confidence intervals (CIs) were pooled using a random-effects model. A total of 3398 colorectal adenomas for 25(OH)D and 1754 colorectal adenomas for VDR were included in the meta-analysis. We identified a significant inverse association between colorectal adenoma (combined RR, 0.93; 95\% CI, 0.87-0.98 per 10 $\mathrm{ng} / \mathrm{mL}$ increase in $25(\mathrm{OH}) \mathrm{D}$ levels). When we examined FokI and BsmI polymorphisms in the meta-analysis, we found no association for either FokI (combined RR, 1.00; 95\% CI, 0.95-1.06) or BsmI (combined RR, 0.99; 95\% CI, 0.93-1.05) in the additive model. These data suggest an inverse association between circulating 25(OH)D levels and colorectal adenoma risk.
\end{abstract}

Key Words: Colorectal adenoma, 25-hydroxyvitamin D, vitamin D receptor, meta-analysis

\section{Introduction}

Vitamin D decreases cancer risk by improving differentiation and apoptosis and decreasing proliferation, invasiveness, metastatic potential, and angiogenesis [1]. Vitamin D is produced by exposing the skin to ultraviolet radiation, which is required for conversion of 7-dehydrocholesterol into vitamin D (cholecalciferol), which is then hydroxylated to 25-hydroxylvitamin D $(25(\mathrm{OH}) \mathrm{D})$ in the liver. This $25(\mathrm{OH}) \mathrm{D}$ is converted to $1,25-$ dihydroxyvitamin $\mathrm{D}(1,25(\mathrm{OH}) 2 \mathrm{D})$ by 1-a-hydroxylase in the kidney [2] and other sites, including the colon [3].

The vitamin D receptor (VDR) binds to $1,25(\mathrm{OH}) 2 \mathrm{D}$ and interacts with target-cell nuclei; thus, mediating the biological actions of vitamin D [4]. Because of the potential importance of VDR in cancer etiology, the associations between variants of the VDR gene and colorectal cancer have been examined in several studies $[5,6]$. The most frequently studied single nucleotide polymorphisms are FokI (rs2228570) and BsmI (rs1544410). The FokI restriction fragment length polymorphism exhibits two isoform VDR proteins that may have different transcription efficiencies [7]; the presence of the restriction site produces the 427-residue isoform (f-allele) of the VDR, whereas the absence of the restriction site results in the 424-residue isoform (F-allele), which may have higher transcriptional activity. The BsmI restriction site in the intron at the $3^{\prime}$-untranslated region of the VDR gene, which is strongly linked with polymorphisms in ApaI, TaqI, and poly(A) and does not change the encoded VDR protein, is associated with bone mineral density [8] and prostate cancer [9]. The B of BsmI denotes the absence of a restriction site, and $b$ denotes the presence of a restriction site.

Given the possible favorable effect of vitamin D against cancer, several epidemiological studies have suggested a possible increased risk for colorectal neoplasia with low vitamin D status [10] or with certain VDR gene alleles [5,6]. Several case-control and prospective studies found inverse or no associations between circulating vitamin D levels and colorectal adenoma [11-19]. We performed a meta-analysis of nine studies, including 3,398 cases and 3,883 controls, to examine whether circulating blood $25(\mathrm{OH})$ levels were inversely associated with colorectal adenoma, a precursor colorectal cancer lesion. We also examined the associations between common FokI and BsmI polymorphisms and colorectal adenoma in a meta-analysis of five studies for each polymorphism.

\footnotetext{
This work was supported by a Sookmyung Women's University Grant (2011).

${ }^{\S}$ Corresponding Author: Jung Eun Lee, Tel. 82-2-2077-7560, Fax. 82-2-710-9479, Email. junglee@sm.ac.kr

Received: Febrary 15, 2011, Revised: May 19, 2011, Accepted: June 23, 2011

(c2011 The Korean Nutrition Society and the Korean Society of Community Nutrition

This is an Open Access article distributed under the terms of the Creative Commons Attribution Non-Commercial License (http://creativecommons.org/licenses/by-nc/3.0/)

which permits unrestricted non-commercial use, distribution, and reproduction in any medium, provided the original work is properly cited.
} 


\section{Subjects and Methods}

\section{Identification and selection of studies}

We searched the PUBMED database for the period before January 2011 using the terms [(vitamin D [MeSH] and "vitamin D" or "25-hydroxyvitamin D") and ("adenoma")] and the EMBASE and MEDLINE databases using the terms [("vitamin D" or "25-hydroxyvitamin D") and ("adenoma")] for circulating vitamin D levels and colorectal adenoma. The search was restricted to human studies reported in English-language articles. In total, 147 abstracts were identified in the PUBMED database and 48 from EMBASE and MEDLINE. We also examined references from these publications to identify further studies. For VDR, we searched the PUBMED, EMBASE, and MEDLINE databases for the period up to January 2011 using the terms [(("vitamin D receptor" or "Fok" or "Bsm") and ("adenoma")) or ("rs2228570" or "rs1544410")]. The search was restricted to human studies reported in English-language articles. In total, 68 abstracts were identified from the PUBMED database and 35 from EMBASE and MEDLINE. We identified nine studies [11-19] that examined serum or plasma $25(\mathrm{OH}) \mathrm{D}$ and first colorectal adenoma or adenoma recurrence, and five studies for each polymorphism $[15,16,20-24]$ that reported the associations between the FokI or BsmI polymorphisms and colorectal adenoma or adenoma recurrence and met the following criteria; 1) serum or plasma $25(\mathrm{OH}) \mathrm{D}$ or VDR FokI or BsmI polymorphisms were assayed as the exposure of interest; 2) the outcome of interest was colorectal adenoma or adenoma recurrence; and 3 ) the relative risk (RR) and $95 \%$ confidence intervals (CIs) were reported.

\section{Statistical analysis}

We extracted the RRs for a standard unit of increase in $25(\mathrm{OH}) \mathrm{D}$ levels and the RRs comparing the top $25(\mathrm{OH}) \mathrm{D}$ categories with the bottom categories. To construct dose-response models if the RR per standard unit of increase was not reported, we fit a linear model to estimate the RRs per $10 \mathrm{ng} / \mathrm{mL}$ increase in circulating vitamin D levels using the method proposed by Greenland and Longnecker [25] and Orsini et al. [26]. For the common VDR polymorphisms FokI and BsmI, we considered the homozygous genotype of the more prevalent allele as the reference group ( $\mathrm{F}$ for FokI and $\mathrm{b}$ for BsmI). We extracted the number of cases and controls for the crude combined RR to combine all studies and present the combined RRs in additive, dominant, and recessive models. We contacted the author of one study to obtain the RRs for FokI polymorphisms in dominant and recessive models, but were unable to obtain the data. For one study [16], which did not report the number of cases or controls by FokI polymorphism but did report the RRs with the reference group of the FF genotype, we used the RRs presented for the additive model but did not include that study for dominant and recessive models because of a lack of information. The results were similar when we compared the combined RRs of the adjusted estimates with the crude combined RR in four studies that reported the adjusted RRs comparing the homozygous genotype of variant type with the homozygous genotype of the wild type (data not shown).

The summary RRs were estimated using a random effects model developed by DerSimonian and Laird [27]. The individual study estimates were weighted by the inverse of their variance. We tested for heterogeneity among studies using the Q statistic [27] and examined heterogeneity by type of study, country, or adjustment for season, body mass index (BMI), and physical activity across studies. Publication bias was assessed using the Egger regression asymmetry test [28]. All statistical analyses were performed with STATA 11 statistical software (StataCorp, College Station, TX, USA). A $P<0.05$ (two sided) was considered statistically significant.

\section{Results}

\section{Circulating 25(OH)D levels and colorectal adenoma}

Nine studies met the inclusion criteria for circulating vitamin D levels and colorectal adenoma (Table 1), including four prospective studies and five case-control studies. Among the four prospective studies, two were trials of adenoma recurrence (treatment reagents were ursodeoxycholic acid in one study [12] and calcium carbonate in the other study [16]), and the other two studies were prospective, which followed participants with updated information on sigmoidoscopy or colonoscopy. In the five case-control studies, blood samples of participants were collected at or after diagnosis of colorectal adenoma. Eight studies were conducted in multiple regions in the US, and one study was conducted in Japan. In total, 3,398 cases and 3,883 controls were included in the meta-analysis of circulating $25(\mathrm{OH}) \mathrm{D}$ levels and colorectal adenoma. Of the nine studies, time of blood draw (season, month, or date) was matched or adjusted in six studies [12-15,18,19], and BMI or physical activity was considered a confounding factor in seven studies [11-15,17,18]. Colorectal adenoma cases were ascertained mostly through colonoscopies in six studies. Five studies [11,15-17,19] reported estimates by calcium intake strata.

We observed a significant inverse association between $25(\mathrm{OH}) \mathrm{D}$ levels and colorectal adenoma (combined RR, 0.93; 95\% CI, $0.87-0.98$ per $10 \mathrm{ng} / \mathrm{mL}$ increase in $25(\mathrm{OH}) \mathrm{D}$ levels (Fig. 1). For a $20 \mathrm{ng} / \mathrm{mL}$ increase in $25(\mathrm{OH}) \mathrm{D}$ levels, the combined RR was 0.84 (95\% CI, 0.73-0.96). When we compared top with bottom categories of $25(\mathrm{OH}) \mathrm{D}$ levels, the combined RR $(95 \%$ CI) was $0.73(0.54-0.92)$. To examine whether there was a tendency for investigators to publish positive findings, we explored asymmetry of a funnel plot. There was no evidence of publication bias at the 0.05 level (Egger's test $P=0.07$ for RRs per $10 \mathrm{ng} / \mathrm{mL}$ 
Table 1. Included studies of circulating levels of $25(\mathrm{OH}) \mathrm{D}$ and risk of colorectal adenoma

\begin{tabular}{|c|c|c|c|c|c|c|c|}
\hline $\begin{array}{l}\text { First author, year } \\
\text { [Ref no.] }\end{array}$ & Country $\left(\operatorname{Sex}^{1)}\right)$ & Study design & Endpoint & Type of endoscopy & $\begin{array}{c}\text { Age at blood } \\
\text { donation in controls } \\
\text { (years) }\end{array}$ & $\begin{array}{l}\text { No. of cases } \\
\text { / controls }\end{array}$ & $25(\mathrm{OH}) \mathrm{D}$, mean or median \\
\hline Platz, 2000 [13] & US (W) & Prospective & First adenoma & $\begin{array}{l}\text { Sigmoidoscopy or } \\
\text { colonoscopy }\end{array}$ & 58.5 in 1990, mean & $326 / 326$ & $\begin{array}{l}26.4 \text { in cases and } 26.8 \\
\mathrm{ng} / \mathrm{mL} \text { in controls, mean }\end{array}$ \\
\hline Levine, 2001 [17] & US $(M, W)$ & Case-control & First adenoma & Sigmoidoscopy & 61.8 , mean & $473 / 506$ & $\begin{array}{l}25.6 \text { in cases and } 26.9 \\
\mathrm{ng} / \mathrm{mL} \text { in controls, mean }\end{array}$ \\
\hline Peters, 2001 [15] & US $(M, W)$ & Case-control & $\begin{array}{l}\text { First }(61 \%) \text { or } \\
\text { recurrent adenoma }\end{array}$ & $\begin{array}{l}\text { Colonoscopy }(86.2 \%) \\
\text { or sigmoidoscopy }\end{array}$ & 57, median & $236 / 218$ & $\begin{array}{l}24.7 \text { in cases and } 26.5 \\
\mathrm{ng} / \mathrm{mL} \text { in controls, median }\end{array}$ \\
\hline Grau, 2003 [16] & US (M, W) & Prospective & Recurrent adenoma & Colonoscopy & 61 , mean & $376 / 422$ & $29.1 \mathrm{ng} / \mathrm{mL}$, median \\
\hline Peters, 2004 [14] & US $(M, W)$ & Prospective & First adenoma & Sigmoidoscopy & 62.3 , mean & $394 / 397$ & $\begin{array}{l}27.0 \text { in cases and } 28.3 \\
\mathrm{ng} / \mathrm{mL} \text { in controls, mean }\end{array}$ \\
\hline Jacobs, 2007 [12] & US $(M, W)$ & Prospective & Recurrent adenoma & $\begin{array}{l}\text { Colonoscopy }(97.7 \%) \\
\left.\text { and sigmoidoscopy }{ }^{2}\right)\end{array}$ & 66.0 , mean & $210 / 358$ & $\begin{array}{l}26.9 \mathrm{ng} / \mathrm{mL} \text { in men, and } \\
25.1 \mathrm{ng} / \mathrm{mL} \text { in women, mean }\end{array}$ \\
\hline Miller, 2007 [19] & US $(M, W)$ & Case-control & First adenoma & Colonoscopy & 54.4 , mean & $111 / 238$ & $\begin{array}{l}27.5 \text { in cases and } 31.4 \\
\mathrm{ng} / \mathrm{mL} \text { in controls, mean }\end{array}$ \\
\hline Takahashi, 2010 [18] & Japan (M, W) & Case-control & First adenoma & Colonoscopy & 51.8 , mean & $656 / 648$ & $\begin{array}{l}26.2 \text { in cases and } 26.1 \\
\mathrm{ng} / \mathrm{mL} \text { in controls, mean }\end{array}$ \\
\hline Fedirko, 2010 [11] & US $(M, W)$ & Case-control & First adenoma & Colonoscopy & 53.6, mean & $616 / 770$ & $\begin{array}{l}24.5 \text { in cases and } 25.5 \\
\mathrm{ng} / \mathrm{mL} \text { in controls, mean }\end{array}$ \\
\hline
\end{tabular}

${ }^{1)} \mathrm{M}$, men; W, women

2) Information was obtained from Alberts et al. [48].

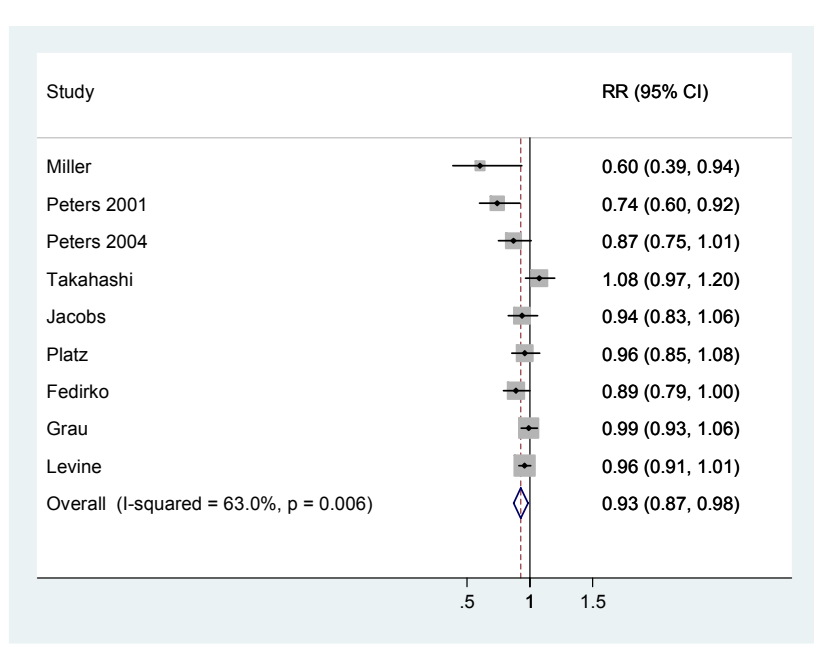

Fig. 1. Study-specific and combined relative risks (RRs) and $95 \%$ confidence intervals (Cls) of colorectal adenoma per $10 \mathrm{ng} / \mathrm{mL}$ increase in blood 25(OH)D levels. Black circles indicate the study-specific relative risks; horizontal lines represent the $95 \% \mathrm{Cls}$. The area of the gray squares reflects the study-specific weights (inverse of the variance). The dashed line represents the combined RR and the diamond represents the $95 \% \mathrm{Cl}$ for the combined $\mathrm{RR}$.

increase in $25(\mathrm{OH}) \mathrm{D}$ levels). We explored the heterogeneity in $25(\mathrm{OH}) \mathrm{D}$ levels across colorectal adenoma studies using sensitivity analyses. After excluding the study conducted in Japan [18], the combined RR $(95 \% \mathrm{CI})$ per $10 \mathrm{ng} / \mathrm{mL}$ increase in 25(OH)D levels was $0.91(0.86-0.97 ; P$ heterogeneity $=0.02)$. When we excluded one study [19], which did not consider the covariance estimate across exposure levels because it did not report the number of subjects [25,26], we found a combined RR of 0.94 (95\% CI, 0.89-0.99) per $10 \mathrm{ng} / \mathrm{mL}$ increase in $25(\mathrm{OH}) \mathrm{D}$ levels. We pooled estimates only among studies that considered season and BMI or physical activity; combined RRs $(95 \% \mathrm{CI})$ per $10 \mathrm{ng} / \mathrm{mL}$ increase in $25(\mathrm{OH}) \mathrm{D}$ levels were $0.89(95 \% \mathrm{CI}$,
$0.79-1.00)$ and 0.93 (95\% CI, 0.87-0.99), respectively. When we excluded two clinical trials of colorectal adenoma recurrence, the results were similar; the combined RR was $0.92(95 \% \mathrm{CI}$, $0.86-0.99)$ per $10 \mathrm{ng} / \mathrm{mL}$ increase in $25(\mathrm{OH}) \mathrm{D}$ levels. The combined RRs (95\% CIs) were 0.96 (0.91-1.01) in a metaanalysis of four prospective studies and 0.89 (0.78-1.00) in a meta-analysis of five case-control studies.

We also examined whether the association varied by calcium status in five studies $[11,15-17,19]$. When we pooled estimates by calcium status (high vs. low), we observed combined RRs of 0.71 (95\% CI, 0.50-0.92) for high calcium status and 0.91 (95\% CI, 0.75-1.06) for low calcium status.

\section{VDR polymorphisms (FokI and BsmI) and colorectal adenoma}

We found five studies for each polymorphism (1754 cases for FokI and 1740 cases for BsmI) that met the inclusion criteria for common polymorphisms of FokI or BsmI in relation to colorectal adenoma occurrence or adenoma recurrence (Table 2). For FokI polymorphisms, the endpoints were colorectal adenoma recurrence in three studies and adenoma occurrence in two studies. For BsmI polymorphisms, one study [23] examined colorectal adenoma recurrences in a randomized clinical trial of calcium carbonate.

We detected no association for the FokI polymorphisms; combined RRs (95\% CIs) were $1.00(0.95-1.06)$ in the additive model (five studies; Fig. 2), 1.04 (0.82-1.25) in the dominant model (three studies), and $0.86(0.60-1.12)$ in the recessive model (three studies). For BsmI polymorphisms, combined RRs (95\% CIs) were 0.99 (0.93-1.05) in the additive model (five studies), 0.96 (0.84-1.09) in the dominant model (five studies), and 1.00 (0.82-1.17) in the recessive model (five studies). Egger's test showed no significant evidence of publication bias $(P=0.95$ for 
Table 2. Included studies of vitamin D receptor polymorphisms (Fokl and Bsml) and risk of colorectal adenoma

\begin{tabular}{|c|c|c|c|c|c|c|c|c|}
\hline $\begin{array}{l}\text { First author, year } \\
\text { (Ref no.) }\end{array}$ & $\begin{array}{l}\text { Country } \\
\left(\text { Sex }^{1)}\right)\end{array}$ & Ethnicity & $\begin{array}{l}\mathrm{MAF}^{2)} \text { in } \\
\text { controls }\end{array}$ & Endpoint & Type of endoscopy & $\begin{array}{l}\text { No. of cases } \\
\text { / non-cases }\end{array}$ & $\begin{array}{c}\text { Fokl } \\
\text { RR }(95 \% \text { Cl) }\end{array}$ & $\begin{array}{c}\text { Bsml } \\
\operatorname{RR}(95 \% \mathrm{Cl}) \\
\end{array}$ \\
\hline Kim, 2001 [20] & US $(M, W)$ & $97 \%$ of Caucasian ${ }^{3)}$ & 0.43 for Bsml & First adenoma & Colonoscopy & $393 / 406$ & - & $\begin{array}{c}0.71(0.46-1.11) \text { for } \\
\text { BB vs. bb }\end{array}$ \\
\hline Ingles, 2001 [21] & US $(M, W)$ & $\begin{array}{c}57 \% \text { of non-Hispanic } \\
\text { white in controls }\end{array}$ & $\begin{array}{l}0.40 \text { for Fokl } \\
0.37 \text { for Bsml }\end{array}$ & First adenoma & Sigmoidoscopy & $373 / 394$ & $\begin{array}{l}0.94(0.60-1.5) \text { for } \\
\text { ff vs. FF }\end{array}$ & $\begin{array}{c}1.1(0.73-1.8) \text { for } \\
\text { BB vs. bb }\end{array}$ \\
\hline Peters, 2001 [15] & US $(M, W)$ & $\begin{array}{c}89 \% \text { of non-Hispanic } \\
\text { white in controls }\end{array}$ & 0.35 for Fokl & $\begin{array}{c}\text { First or recurrent } \\
\text { adenoma }\end{array}$ & $\begin{array}{l}\text { Colonoscopy }(86.2 \%) \\
\text { or sigmoidoscopy }\end{array}$ & $208 / 184$ & $\begin{array}{c}0.75 \text { (0.36-1.58) for } \\
\text { FF vs. ff }\end{array}$ & - \\
\hline Boyapati, 2003 [22] & US $(M, W)$ & $\begin{array}{c}90.2 \% \text { of Caucasian } \\
\text { in controls }\end{array}$ & 0.45 for Bsml & First adenoma & Colonoscopy & $177 / 228$ & - & $\begin{array}{c}0.87(0.53-1.45) \text { for } \\
\text { bb vs. BB }\end{array}$ \\
\hline Grau, 2003 [16] & US $(M, W)$ & $84 \%$ of Caucasian & 0.36 for Fokl ${ }^{4)}$ & $\begin{array}{l}\text { Recurrent } \\
\text { adenoma }\end{array}$ & Colonoscopy & $376 / 422$ & $\begin{array}{l}1.06(0.86-1.32) \text { for } \\
\text { ff vs. FF }\end{array}$ & - \\
\hline Hubner, 2008 [23] & UK $(M, W)$ & $100 \%$ Caucasian & $\begin{array}{l}0.38 \text { for Fokl } \\
0.40 \text { for Bsml }\end{array}$ & $\begin{array}{l}\text { Recurrent } \\
\text { adenoma }\end{array}$ & Colonoscopy & $137 / 409$ & $\begin{array}{l}0.92(0.58-1.46) \text { for } \\
\text { ff vs. FF }\end{array}$ & $\begin{array}{c}1.07(0.73-1.57) \text { for } \\
\text { BB vs bb }\end{array}$ \\
\hline Egan, 2010 [24] & US $(M, W)$ & $95 \%$ of Caucasian & $\mathrm{N} / \mathrm{A}$ & $\begin{array}{l}\text { Recurrent } \\
\text { adenoma }\end{array}$ & Colonoscopy $y^{5)}$ & $660 / 779$ & $\begin{array}{l}0.93(0.80-1.09) \text { in } \\
\text { additive model }\end{array}$ & $\begin{array}{l}1.01(0.87-1.18) \text { in } \\
\text { additive model }\end{array}$ \\
\hline
\end{tabular}

${ }^{1)} \mathrm{M}$, men; W, women

${ }^{2)}$ Minor allele frequency

3) We obtained information on ethnicity from Smith-Warner et al. [49].

4) Among all participants

5) We obtained information on type of endoscopy from Alberts et al. [50] and Alberts et al. [48].

(A) Fokl and colorectal adenoma

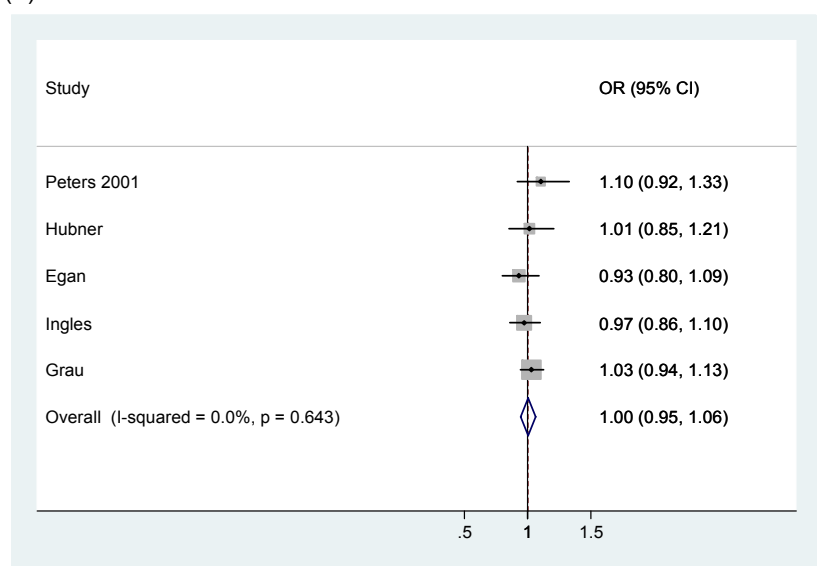

(B) Bsml and colorectal adenoma

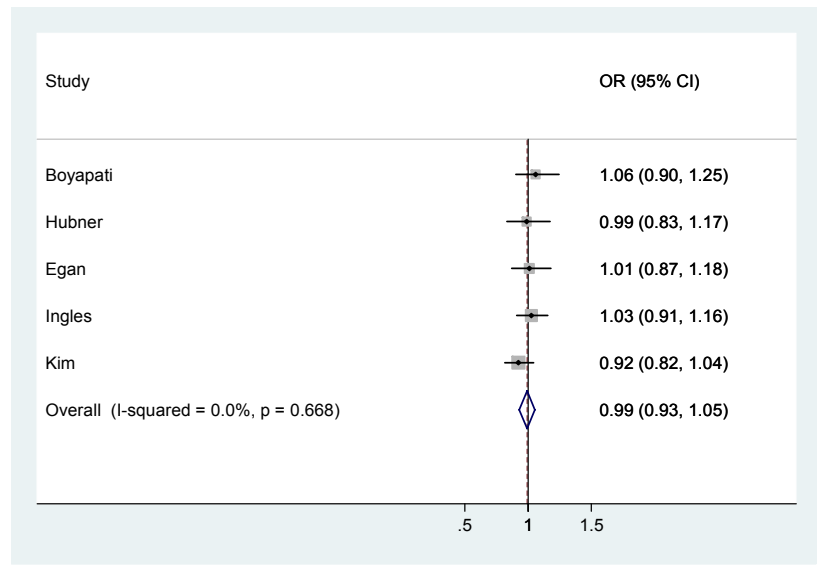

Fig. 2. Study-specific and combined relative risks (RRs) and $95 \%$ confidence intervals (Cls) for colorectal adenoma according to Fokl and Bsml polymorphisms in the additive model. Black circles indicate study-specific odds ratios; horizontal lines represent the $95 \% \mathrm{Cls}$. The area of the gray squares reflects the study-specific weights (inverse of the variance). The dashed line represents the combined $\mathrm{RR}$ and the diamond represents the $95 \% \mathrm{Cl}$ for the combined RR.
FokI and $P=0.53$ for BsmI in the additive model). We also pooled adjusted RRs shown in the articles; the combined RR $(95 \%$ CI) was $1.02(0.84-1.21)$ for ff vs. FF genotype of FokI and $0.93(0.71-1.15)$ for BB vs. bb of BsmI in four studies.

\section{Discussion}

We found an inverse association between circulating vitamin D levels and the risk for colorectal adenoma. However, we did not observe any associations between common FokI and BsmI polymorphisms and colorectal adenoma in this meta-analysis.

The hypothesis that vitamin D may prevent colorectal neoplasia has been supported by both experimental evidence and summaries of epidemiological studies on circulating vitamin D levels. Vitamin D may reduce the risk of colorectal neoplasia by regulating progression and differentiation [1] and inhibiting angiogenesis [29]. This hypothesis is supported by animal studies showing that vitamin D (the vitamin D3 analogue EB 1,089) improves tumor control following radiation treatment, possibly by promoting apoptosis [30]. Based on the geographic distribution of colon cancer mortality rates in the US, with the highest rates in regions with the least amount of sunlight, Garland and Garland hypothesized that vitamin D protects against colon cancer [31]. A recent systematic review of serum or plasma $25(\mathrm{OH}) \mathrm{D}$ levels and colorectal cancer incidence reported a 34\% lower risk of colorectal cancer among individuals in the top quintiles compared to those in the bottom quintiles [32], which agrees with our meta-analysis results for colorectal adenoma. A previous meta-analysis of seven circulating vitamin $\mathrm{D}$ level and colorectal adenoma studies showed a RR of 0.70 (95\% CI, 0.56-0.87) by comparing the highest with lowest quintile of $25(\mathrm{OH}) \mathrm{D}$ levels [33]. When we included two more studies $[11,18]$, we found a $7 \%$ decreased risk for colorectal adenoma per $10 \mathrm{ng} / \mathrm{mL}$ increase 
in $25(\mathrm{OH}) \mathrm{D}$ levels, and our results were robust in multiple sensitivity analyses. Our meta-analysis results of five calcium status studies suggested that calcium and vitamin D may interact in the development of colorectal adenoma, which has been the subject of several previous studies with inconsistent findings [34-37]. This warrants further study. Given the high prevalence of vitamin D insufficiency in Korea [38], US, and Canada [39], the role of vitamin $\mathrm{D}$ in chronic disease development may merit priority for future research.

The cellular effects of $1,25(\mathrm{OH}) 2 \mathrm{D}$ are mediated primarily through binding to the nuclear VDR, which regulates the transcription of numerous genes, including protooncogenes and tumor suppressor genes [40]. Normal epithelial colon cells and cancer cells express VDR [41]. Epidemiological studies have examined the association between VDR polymorphisms and colorectal cancer, because of great interest in the preventive effect of vitamin D in relation to cancer at several sites [10]. The most frequently assessed genotypes are FokI and BsmI. However, a meta-analysis of FokI and BsmI and colorectal cancer incidence yielded no significant associations [6]. Our meta-analysis of colorectal adenoma also showed no association with FokI or BsmI polymorphisms. Previous studies have reported inconsistent findings for other VDR polymorphisms in relation to colorectal adenoma or cancer [14,23,24,42-45].

Each study relied upon a single measure of plasma vitamin D metabolite levels, which did not allow us to examine changes across time. However, a single measure of vitamin D metabolites is a useful marker for long-term vitamin D status [46,47]. Although we cannot rule out residual or unmeasured confounding factors, the combined estimates from studies that controlled for season, BMI, or physical activity still showed significant or marginally significant inverse associations, suggesting that our results may not be entirely explained by bias due to confounding factors. The combined adjusted RRs (when available) also showed no association for FokI or BsmI polymorphisms, which is in agreement with the combined crude RRs. The heterogeneity we found across studies in the meta-analysis may be due to differences in laboratory measurement methods, follow-up periods, seasons of blood draw, exposure to sunlight, ethnicity, or the prevalence of interaction factors and unknown/unmeasured confounding factors. The majority of our population was Caucasian for the combined estimates of VDR polymorphisms; thus this result is not generalizable to other populations.

In summary, our meta-analysis found a significant inverse association between $25(\mathrm{OH}) \mathrm{D}$ levels and colorectal adenoma. No significant association between FokI or BsmI polymorphisms and colorectal adenoma was detected. Further prospective studies or randomized clinical trials of vitamin $\mathrm{D}$ in relation to colorectal neoplasia and other VDR gene polymorphisms may be necessary.

\section{Acknowledgement}

The author thanks Dr. Nicola Orsini for his advice on statistical analysis.

\section{References}

1. Lamprecht SA, Lipkin M. Cellular mechanisms of calcium and vitamin $\mathrm{D}$ in the inhibition of colorectal carcinogenesis. Ann N Y Acad Sci 2001;952:73-87.

2. Fraser DR. Biochemical and clinical aspects of vitamin D function. Br Med Bull 1981;37:37-42.

3. Tangpricha V, Flanagan JN, Whitlatch LW, Tseng CC, Chen TC, Holt PR, Lipkin MS, Holick MF. 25-hydroxyvitamin D-1alphahydroxylase in normal and malignant colon tissue. Lancet 2001; 357:1673-4.

4. Baker AR, McDonnell DP, Hughes M, Crisp TM, Mangelsdorf DJ, Haussler MR, Pike JW, Shine J, O'Malley BW. Cloning and expression of full-length cDNA encoding human vitamin D receptor. Proc Natl Acad Sci U S A 1988;85:3294-8.

5. Slattery ML. Vitamin D receptor gene (VDR) associations with cancer. Nutr Rev 2007;65:S102-4.

6. Raimondi S, Johansson H, Maisonneuve P, Gandini S. Review and meta-analysis on vitamin $\mathrm{D}$ receptor polymorphisms and cancer risk. Carcinogenesis 2009;30:1170-80.

7. Arai $\mathrm{H}$, Miyamoto $\mathrm{K}$, Taketani $\mathrm{Y}$, Yamamoto $\mathrm{H}$, Iemori $\mathrm{Y}$, Morita K, Tonai T, Nishisho T, Mori S, Takeda E. A vitamin $\mathrm{D}$ receptor gene polymorphism in the translation initiation codon: effect on protein activity and relation to bone mineral density in Japanese women. J Bone Miner Res 1997;12:915-21.

8. Cooper GS, Umbach DM. Are vitamin D receptor polymorphisms associated with bone mineral density? A meta-analysis. J Bone Miner Res 1996;11:1841-9.

9. Habuchi T, Suzuki T, Sasaki R, Wang L, Sato K, Satoh S, Akao T, Tsuchiya N, Shimoda N, Wada Y, Koizumi A, Chihara J, Ogawa $\mathrm{O}$, Kato $\mathrm{T}$. Association of vitamin $\mathrm{D}$ receptor gene polymorphism with prostate cancer and benign prostatic hyperplasia in a Japanese population. Cancer Res 2000;60:305-8.

10. Giovannucci E. The epidemiology of vitamin D and cancer incidence and mortality: a review (United States). Cancer Causes Control 2005;16:83-95

11. Fedirko V, Bostick RM, Goodman M, Flanders WD, Gross MD. Blood 25-hydroxyvitamin D3 concentrations and incident sporadic colorectal adenoma risk: a pooled case-control study. Am J Epidemiol 2010;172:489-500.

12. Jacobs ET, Alberts DS, Benuzillo J, Hollis BW, Thompson PA, Martínez ME. Serum 25(OH)D levels, dietary intake of vitamin $\mathrm{D}$, and colorectal adenoma recurrence. J Steroid Biochem Mol Biol 2007;103:752-6.

13. Platz EA, Hankinson SE, Hollis BW, Colditz GA, Hunter DJ, Speizer FE, Giovannucci E. Plasma 1,25-dihydroxy- and 25hydroxyvitamin D and adenomatous polyps of the distal colorectum. Cancer Epidemiol Biomarkers Prev 2000;9:1059-65.

14. Peters U, Hayes RB, Chatterjee N, Shao W, Schoen RE, Pinsky P, Hollis BW, McGlynn KA; Prostate, Lung, Colorectal and Ovarian Cancer Screening Project Team. Circulating vitamin D metabolites, polymorphism in vitamin D receptor, and colorectal adenoma risk. Cancer Epidemiol Biomarkers Prev 2004;13: 
546-52.

15. Peters U, McGlynn KA, Chatterjee N, Gunter E, Garcia-Closas M, Rothman N, Sinha R. Vitamin D, calcium, and vitamin D receptor polymorphism in colorectal adenomas. Cancer Epidemiol Biomarkers Prev 2001;10:1267-74.

16. Grau MV, Baron JA, Sandler RS, Haile RW, Beach ML, Church TR, Heber D. Vitamin D, calcium supplementation, and colorectal adenomas: results of a randomized trial. J Natl Cancer Inst 2003;95:1765-71.

17. Levine AJ, Harper JM, Ervin CM, Chen YH, Harmon E, Xue S, Lee ER, Frankel HD, Haile RW. Serum 25-hydroxyvitamin $\mathrm{D}$, dietary calcium intake, and distal colorectal adenoma risk. Nutr Cancer 2001;39:35-41.

18. Takahashi R, Mizoue T, Otake T, Fukumoto J, Tajima O, Tabata $\mathrm{S}$, Abe H, Ohnaka K, Kono S. Circulating vitamin D and colorectal adenomas in Japanese men. Cancer Sci 2010;101: 1695-700.

19. Miller EA, Keku TO, Satia JA, Martin CF, Galanko JA, Sandler RS. Calcium, dietary, and lifestyle factors in the prevention of colorectal adenomas. Cancer 2007;109:510-7.

20. Kim HS, Newcomb PA, Ulrich CM, Keener CL, Bigler J, Farin FM, Bostick RM, Potter JD. Vitamin D receptor polymorphism and the risk of colorectal adenomas: evidence of interaction with dietary vitamin D and calcium. Cancer Epidemiol Biomarkers Prev 2001;10:869-74.

21. Ingles SA, Wang J, Coetzee GA, Lee ER, Frankl HD, Haile RW. Vitamin D receptor polymorphisms and risk of colorectal adenomas (United States). Cancer Causes Control 2001;12:607-14.

22. Boyapati SM, Bostick RM, McGlynn KA, Fina MF, Roufail WM, Geisinger KR, Wargovich M, Coker A, Hebert JR. Calcium, vitamin $\mathrm{D}$, and risk for colorectal adenoma: dependency on vitamin D receptor BsmI polymorphism and nonsteroidal antiinflammatory drug use? Cancer Epidemiol Biomarkers Prev 2003; 12:631-7.

23. Hubner RA, Muir KR, Liu JF, Logan RF, Grainge MJ, Houlston RS; Members of UKCAP Consortium. Dairy products, polymorphisms in the vitamin D receptor gene and colorectal adenoma recurrence. Int J Cancer 2008;123:586-93.

24. Egan JB, Thompson PA, Ashbeck EL, Conti DV, Duggan D, Hibler E, Jurutka PW, Leroy EC, Martinez ME, Mount D, Jacobs ET. Genetic polymorphisms in vitamin D receptor VDR/RXRA influence the likelihood of colon adenoma recurrence. Cancer Res 2010;70:1496-504.

25. Greenland S, Longnecker MP. Methods for trend estimation from summarized dose-response data, with applications to meta-analysis. Am J Epidemiol 1992;135:1301-9.

26. Orsini N, Bellocco R, Greenland S. Generalized least squares for trend estimation of summarized dose-response data. Stata $\mathrm{J}$ 2006;6:40-57.

27. DerSimonian R, Laird N. Meta-analysis in clinical trials. Control Clin Trials 1986;7:177-88.

28. Egger M, Davey Smith G, Schneider M, Minder C. Bias in meta-analysis detected by a simple, graphical test. BMJ 1997; 315:629-34.

29. Iseki K, Tatsuta M, Uehara H, Iishi H, Yano H, Sakai N, Ishiguro $\mathrm{S}$. Inhibition of angiogenesis as a mechanism for inhibition by 1alpha-hydroxyvitamin D3 and 1,25-dihydroxyvitamin D3 of colon carcinogenesis induced by azoxymethane in Wistar rats. Int J Cancer 1999;81:730-3.

30. Sundaram S, Sea A, Feldman S, Strawbridge R, Hoopes PJ,
Demidenko E, Binderup L, Gewirtz DA. The combination of a potent vitamin D3 analog, EB 1089, with ionizing radiation reduces tumor growth and induces apoptosis of MCF-7 breast tumor xenografts in nude mice. Clin Cancer Res 2003;9:2350-6.

31. Garland CF, Garland FC. Do sunlight and vitamin D reduce the likelihood of colon cancer? Int J Epidemiol 1980;9:227-31.

32. Lee JE, Li H, Chan AT, Hollis BW, Lee IM, Stampfer MJ, Wu K, Giovannucci E, Ma J. Circulating levels of vitamin D and colon and rectal cancer: the Physicians' Health Study and a meta-analysis of prospective studies. Cancer Prev Res (Phila) 2011;4:735-43

33. Wei MY, Garland CF, Gorham ED, Mohr SB, Giovannucci E. Vitamin D and prevention of colorectal adenoma: a metaanalysis. Cancer Epidemiol Biomarkers Prev 2008;17:2958-69.

34. Bostick RM, Potter JD, Sellers TA, McKenzie DR, Kushi LH, Folsom AR. Relation of calcium, vitamin D, and dairy food intake to incidence of colon cancer among older women. The Iowa Women's Health Study. Am J Epidemiol 1993;137:1302-17.

35. Kampman E, Slattery ML, Caan B, Potter JD. Calcium, vitamin $\mathrm{D}$, sunshine exposure, dairy products and colon cancer risk (United States). Cancer Causes Control 2000;11:459-66.

36. Zheng W, Anderson KE, Kushi LH, Sellers TA, Greenstein J, Hong CP, Cerhan JR, Bostick RM, Folsom AR. A prospective cohort study of intake of calcium, vitamin D, and other micronutrients in relation to incidence of rectal cancer among postmenopausal women. Cancer Epidemiol Biomarkers Prev 1998;7:221-5.

37. Wu K, Willett WC, Fuchs CS, Colditz GA, Giovannucci EL. Calcium intake and risk of colon cancer in women and men. $\mathrm{J}$ Natl Cancer Inst 2002;94:437-46.

38. Choi HS, Oh HJ, Choi H, Choi WH, Kim JG, Kim KM, Kim KJ, Rhee Y, Lim SK. Vitamin D insufficiency in Korea--a greater threat to younger generation: the Korea National Health and Nutrition Examination Survey (KNHANES) 2008. J Clin Endocrinol Metab 2011;96:643-51.

39. Calvo MS, Whiting SJ. Prevalence of vitamin D insufficiency in Canada and the United States: importance to health status and efficacy of current food fortification and dietary supplement use. Nutr Rev 2003;61:107-13.

40. Norman AW. Minireview: vitamin D receptor: new assignments for an already busy receptor. Endocrinology 2006;147:5542-8.

41. Kállay E, Bareis P, Bajna E, Kriwanek S, Bonner E, Toyokuni $\mathrm{S}$, Cross HS. Vitamin D receptor activity and prevention of colonic hyperproliferation and oxidative stress. Food Chem Toxicol 2002;40:1191-6.

42. Flügge J, Krusekopf S, Goldammer M, Osswald E, Terhalle W, Malzahn U, Roots I. Vitamin D receptor haplotypes protect against development of colorectal cancer. Eur J Clin Pharmacol 2007;63:997-1005.

43. Poynter JN, Jacobs ET, Figueiredo JC, Lee WH, Conti DV, Campbell PT, Levine AJ, Limburg P, Le Marchand L, Cotterchio M, Newcomb PA, Potter JD, Jenkins MA, Hopper JL, Duggan DJ, Baron JA, Haile RW. Genetic variation in the vitamin D receptor (VDR) and the vitamin D-binding protein (GC) and risk for colorectal cancer: results from the Colon Cancer Family Registry. Cancer Epidemiol Biomarkers Prev 2010;19:525-36.

44. Slatter ML, Yakumo K, Hoffman M, Neuhausen S. Variants of the VDR gene and risk of colon cancer (United States). Cancer Causes Control 2001;12:359-64.

45. Sweeney C, Curtin K, Murtaugh MA, Caan BJ, Potter JD, 
Slattery ML. Haplotype analysis of common vitamin D receptor variants and colon and rectal cancers. Cancer Epidemiol Biomarkers Prev 2006;15:744-9.

46. Hofmann JN, Yu K, Horst RL, Hayes RB, Purdue MP. Longterm variation in serum 25-hydroxyvitamin $\mathrm{D}$ concentration among participants in the Prostate, Lung, Colorectal, and Ovarian Cancer Screening Trial. Cancer Epidemiol Biomarkers Prev 2010;19: 927-31.

47. Platz EA, Leitzmann MF, Hollis BW, Willett WC, Giovannucci E. Plasma 1,25-dihydroxy- and 25-hydroxyvitamin D and subsequent risk of prostate cancer. Cancer Causes Control 2004;15:255-65.

48. Alberts DS, Martínez ME, Hess LM, Einspahr JG, Green SB, Bhattacharyya AK, Guillen J, Krutzsch M, Batta AK, Salen G, Fales L, Koonce K, Parish D, Clouser M, Roe D, Lance P;
Phoenix and Tucson Gastroenterologist Networks. Phase III trial of ursodeoxycholic acid to prevent colorectal adenoma recurrence. J Natl Cancer Inst 2005;97:846-53.

49. Smith-Warner SA, Elmer PJ, Fosdick L, Randall B, Bostick RM, Grandits G, Grambsch P, Louis TA, Wood JR, Potter JD. Fruits, vegetables, and adenomatous polyps: the Minnesota Cancer Prevention Research Unit case-control study. Am J Epidemiol 2002;155:1104-13

50. Alberts DS, Martínez ME, Roe DJ, Guillén-Rodríguez JM, Marshall JR, van Leeuwen JB, Reid ME, Ritenbaugh C, Vargas PA, Bhattacharyya AB, Earnest DL, Sampliner RE. Lack of effect of a high-fiber cereal supplement on the recurrence of colorectal adenomas. Phoenix Colon Cancer Prevention Physicians' Network. N Engl J Med 2000;342:1156-62. 